\title{
Thyroid Function in Human Obesity: Underlying Mechanisms
}

Authors

Affiliations

Key words

- adipose tissue

- thyrotropin

triiodothyronine

- thyroxine

received 23.07.2016 accepted 03.11.2016

Bỉbliography DOI http://dx.doi.org/ 10.1055/s-0042-121421 Horm Metab Res 2016; 48: 787-794

(c) Georg Thieme Verlag KG Stuttgart · New York ISSN 0018-5043

Correspondence

Professor Dr. D. do Nascimento Marreiro 665 Ed. Palazzo Reale Hugo Napoleão St. apt 2001 Jóquei Teresina, Piauí Brazil 64048320

Tel.: + 55/86/999915 019/

$+55 / 86 / 988459778$

Fax: $+55 / 86 / 32371812$

dilina.marreiro@gmail.com

L. C. Fontenelle ${ }^{1}$, M. M. Feitosa ${ }^{1}$, J. S. Severo', T. E. C. Freitas ${ }^{1}$, J. B. S. Morais ${ }^{1}$, F. L. Torres-Leal ${ }^{2}$, G. S. Henriques ${ }^{3}$, D. do Nascimento Marreiro

Department of Nutrition, Federal University of Piauí, Teresina, Piauí, Brazil

'Department of Biophysics and Physiology, Federal University of Piauí, Campus Ministro Petrônio Portela, Ininga, Teresina, Piauí, Brazil

Department of School of Nursing, Federal University of Minas Gerais, Santa Efigênia, Belo Horizonte, Minas Gerais, Brazil

\section{Abstract \\ $\nabla$}

Obesity is associated with several metabolic and endocrine disorders; and changes in plasma concentrations, secretion patterns, and clearance of various hormones are observed in obese patients. In this context, recent research has shown that overweight can influence the function of the thyroid gland, usually leading to increased thyrotropin concentrations and changes in the ratio between the hormones triiodothyronine and thyroxine, though within the normal range. The etiology of these changes is still unclear; how-

\section{Introduction}

\section{$\nabla$}

Obesity is a chronic disease characterized by excessive accumulation of body fat resulting from the interaction between environmental and genetic factors, and a positive energy balance. This condition leads to adipocyte hypertrophy with resultant dysfunction of white adipose tissue, resulting in the development of hypoxia, oxidative stress, and inflammation $[1,2]$.

Due to the endocrine role of adipose tissue and its importance in homeostasis, the dysfunction of this tissue in obesity contributes to metabolic alterations in various organs and systems $[3,4]$. In this respect, endocrine disorders stand out, and changes are observed in plasma levels, secretion patterns, and clearance of various hormones in obese individuals $[5,6]$.

Regarding thyroid function, research has revealed the existence of a positive correlation between adiposity parameters and serum thyrotropin (TSH) and triiodothyronine (T3) in euthyroid individuals, suggesting a possible influence of obesity on the functioning of the hypothalamuspituitary-thyroid axis and the activity of deiodinases [7-11].

Changes in thyroid function, even within the normal range, may contribute to the worsening of ever, several mechanisms have been proposed including the adaptive process to increase energy expenditure, hyperleptinemia, changes in the activity of deiodinases, the presence of thyroid hormones resistance, chronic low-grade inflammation, and insulin resistance. Although the clinical implications have not been clarified, studies suggest that these changes in the thyroid function of obese individuals may contribute to the worsening of metabolic complications and the development of diseases in the thyroid gland.

metabolic complications and the development of diseases in the thyroid gland. In this context, it is worth mentioning that high levels of TSH and T3 have been positively associated with components of metabolic syndrome, and specifically higher serum TSH levels have been linked to increased risk of thyroid cancer [12-16].

Thus, considering the complexity of the pathogenesis of obesity and the impact of this disease on the function of the thyroid gland and thyroid hormone metabolism, this review aims to bring forward up-to-date information on the possible mechanisms involved in the changes in thyroid function in obese individuals.

\section{Thyroid Hormone Metabolism \\ $\nabla$}

Thyroid hormones are synthesized by follicular cells of the thyroid gland from thyroglobulin molecules. First, iodide is taken up by these cells via the sodium/iodide symporter in a process dependent on the electrochemical gradient generated by $\mathrm{Na}^{+} / \mathrm{K}^{+}$-ATPase. In thyroid follicles, iodide is incorporated into the phenolic ring of tyrosine residues of thyroglobulin protein; the enzyme thyroid peroxidase and appropriate concentrations of hydrogen peroxide $\left(\mathrm{H}_{2} \mathrm{O}_{2}\right)$ are 
required for this reaction $[17,18]$. As the molar ratio of thyroxine (T4) to T3 in human thyroglobulin is $15: 1$, T4 is the main product secreted by the thyroid gland, and T3 is mainly produced from T4 deiodination in other tissues [19].

Deiodination involves the removal of an iodine atom from iodothyronine molecules and the reaction is catalyzed by deiodinase enzymes D1, D2, and D3. This process regulates plasma and tissue concentrations of thyroid hormones, controlling the synthesis of T3 as well as inactivation of these hormones in the body. D1 catalyzes iodine removal from T4 phenolic ring, thus activating it, or from its tyrosyl ring, leading to its inactivation. This enzyme provides T3 for circulation, and is also involved in the process of thyroid hormone clearance and recycling of iodine. D2 is present intracellularly and is primarily responsible for the conversion of T4 to T3 in the tissues. D3 only catalyzes the inactivation of thyroid hormones [20].

In cells, thyroid hormones exert their physiological effects via binding to their specific nuclear receptors (TR $\alpha$ and TR $\beta$ ) or to other receptors in mitochondria, in the cytoplasm or at the plasma membrane, which regulate cell signaling pathways, including intracellular mitogen-activated protein kinase (MAPK 1 and 2) and phosphatidylinositol-3-kinase (PI3K). It is important to mention that T3 is the major contributor to genomic actions, as nuclear receptors for these hormones have 10-15 times higher affinity for T3 than for T4. In turn, T4, considered as a pro-hormone, plays an important role in non-genomic actions [21,22].

Thyroid hormones have complex mechanisms of homeostatic control involving multiple feedback loops, which act to maintain serum T3 levels within the normal range and are influenced by various genetic, physiological, pathological, and environmental factors. The classic feedback mechanism refers to the negative control exerted by plasma T3 concentrations and that derived from the hypothalamic and pituitary deiodination of T4 on the expression and secretion of TRH in the hypothalamic paraventricular nucleus and TSH by thyrotrophs in the anterior pituitary $[19,23,24]$. TSH acts by regulating the thyroid gland function and has as one of its actions promoting the D1 synthesis and activity through increasing intracellular cAMP concentrations. This effect also seems to be exerted on the D2 enzyme activity in other peripheral tissues that have functional receptors for this hormone, such as brown adipose tissue and bone [23,25]. Other feedback loops involve the inhibitory effect that TSH has on its own secretion, as well as various mechanisms of peripheral regulation of thyroid hormones that control bioavailability and cellular bioactivity $[23,26]$.

\section{Etiology of Changes in Thyroid Status in Obesity} $\nabla$

The relationship between obesity and the thyroid is complex and bidirectional. In the literature, it is well established that dysfunction in this gland (hypothyroidism or hyperthyroidism) results in changes in body weight because of the participation of thyroid hormones in the control of thermogenesis and appetite. However, recent research has shown that excess weight can also influence thyroid function, with the presence of hyperthyrotropinemia, with or without changes in T3 and T4 concentrations, generally being observed in euthyroid obese subjects $[27,28]$. Table 1 and $\odot$ Fig. 1 present the main results of human studies evaluating thyroid function in obesity.

However, it is not possible to establish whether these changes in thyroid function are primary or secondary to obesity $[8,53]$. In this regard, several studies suggest that dysfunction of adipose tissue is the main factor responsible for changes in the homeostasis of thyroid hormones, which is borne out by the observation that weight loss reverses or mitigates these changes $[10,11,54,55]$.

Notably, longitudinal studies have established the relationship between the concentrations of thyroid hormones and changes in body weight over time. Bjergved et al. [29] observed that an increase of $1 \mathrm{mU} / \mathrm{l}$ of TSH was associated with a weight gain of $0.6 \mathrm{~kg}$ for women and $0.7 \mathrm{~kg}$ for men. Soriguer et al. [30] reported a relative risk of becoming obese of 2.94 and 3.06 in euthyroid individuals with higher levels of $\mathrm{T} 3$ and $\mathrm{T} 4$, respectively, when compared with patients in the lowest quartile.

The etiology of these changes on hypothalamic-pituitary-thyroid axis in obesity is still unclear. However, several mechanisms have been proposed, among which are those related to the adaptive process to increase energy expenditure, the influence of leptin, changes in the activity of deiodinases, the presence of central or peripheral resistance to thyroid hormones, the chronic lowgrade inflammation, and the presence of insulin resistance. - Fig. 2 shows a schematic of the main mechanisms suggested.

\section{Energy expenditure}

The literature suggests that the increase in serum TSH and T3 levels observed in obese individuals occur so as to increase energy expenditure and minimize weight gain $[56,57]$. This assumption is justified by the role of thyroid hormones in the acceleration of energy metabolism and ATP turnover, especially in the induction of thermogenesis by stimulating the expression and activity of energy uncoupling protein (UCP) $[27,57,58]$.

In this scenario, it is worth mentioning that levels of resting energy expenditure rise in obesity, probably due to the concomitant increase in fat-free mass [59]. However, studies conducted in euthyroid obese individuals revealed no association between energy expenditure and concentrations of serum TSH, and free T3 and T4 [60,61]. One possible explanation for this is the impairment of thyroid hormones action to induce thermogenesis in obesity because adipose tissue, in these individuals, especially the visceral, has reduced expression of thyroid hormone receptors, D2 and D3 enzymes, $\beta 2$ and $\beta 3$ adrenergic receptors, and UCP-2 [62].

\section{Hyperleptinemia}

In obesity, the presence of hyperleptinemia is another important factor for the manifestation of changes in the hypothalamicpituitary-thyroid axis. This is due to the regulatory role of leptin, which by promoting TRH expression and synthesis in paraventricular hypothalamic nucleus (direct route) and arcuate nucleus (indirect route), stimulates TSH secretion by the pituitary gland that may favor an increase in the serum levels of this hormone in obese individuals [63].

In the paraventricular hypothalamic nucleus, leptin, through its $\mathrm{ObRb}$ receptor, activates phosphorylation of the transcription factor STAT3 (signal transducer and activator of transcription 3), favoring its binding to promoter region of the gene coding for $\mathrm{TRH}$. In the arcuate nucleus, leptin activates a subpopulation of neurons expressing proopiomelanocortin (POMC), while inhibiting neurons that synthesize Agouti-related protein (AgRP) and neuropeptide $Y$ (NPY). This action leads to increased production of $\alpha$-melanocyte stimulating hormone ( $\alpha$-MSH), which, in turn, is able to stimulate TRH expression by hypothalamic neurons by binding to the melanocortin 4 receptor (MC4-R) [64,65]. 

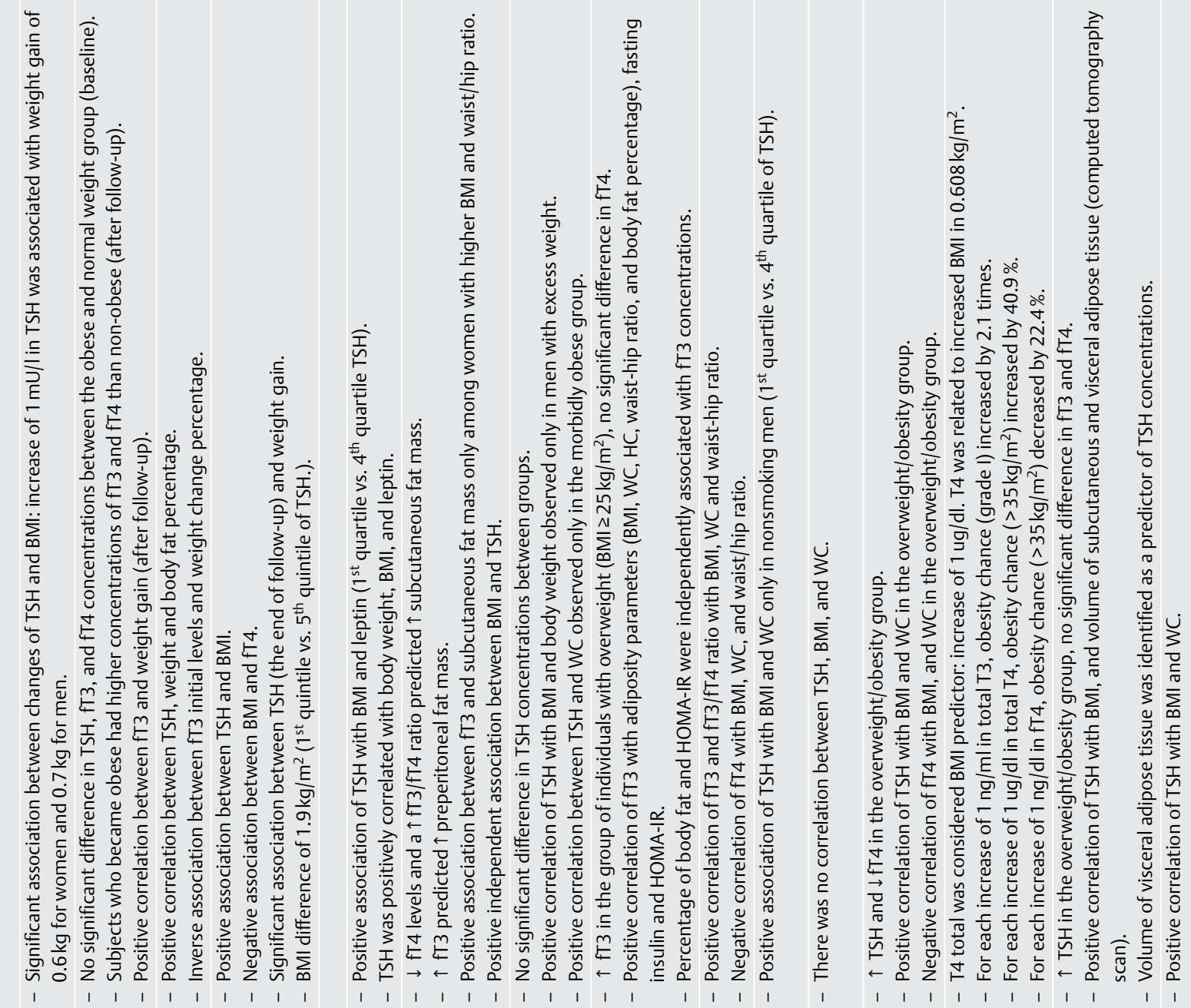

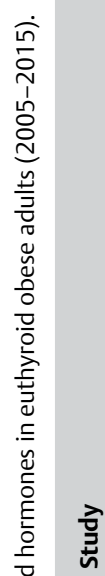

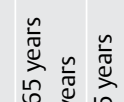

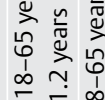

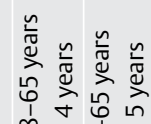

过

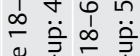

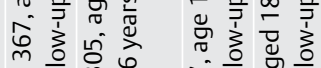
m응

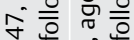

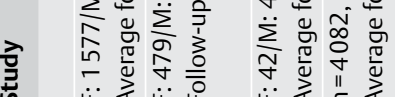

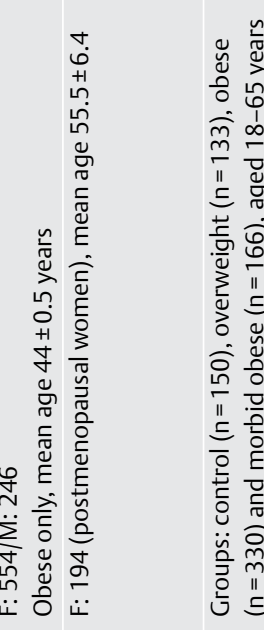

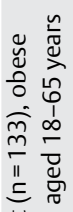

喜通

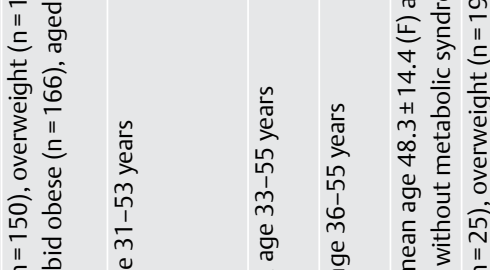

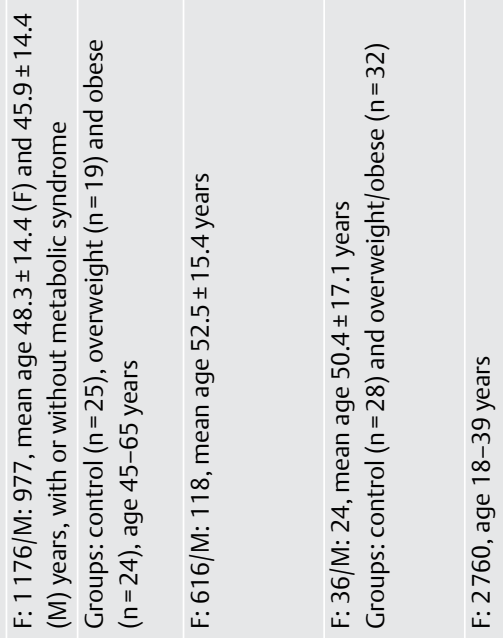

蛋

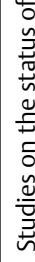

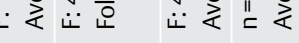

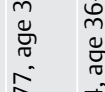

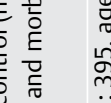

离

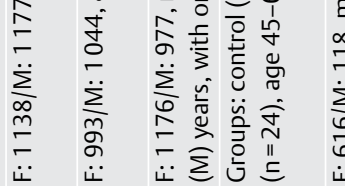

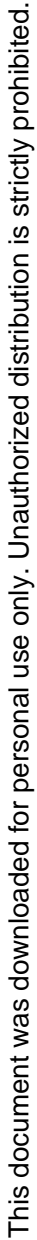




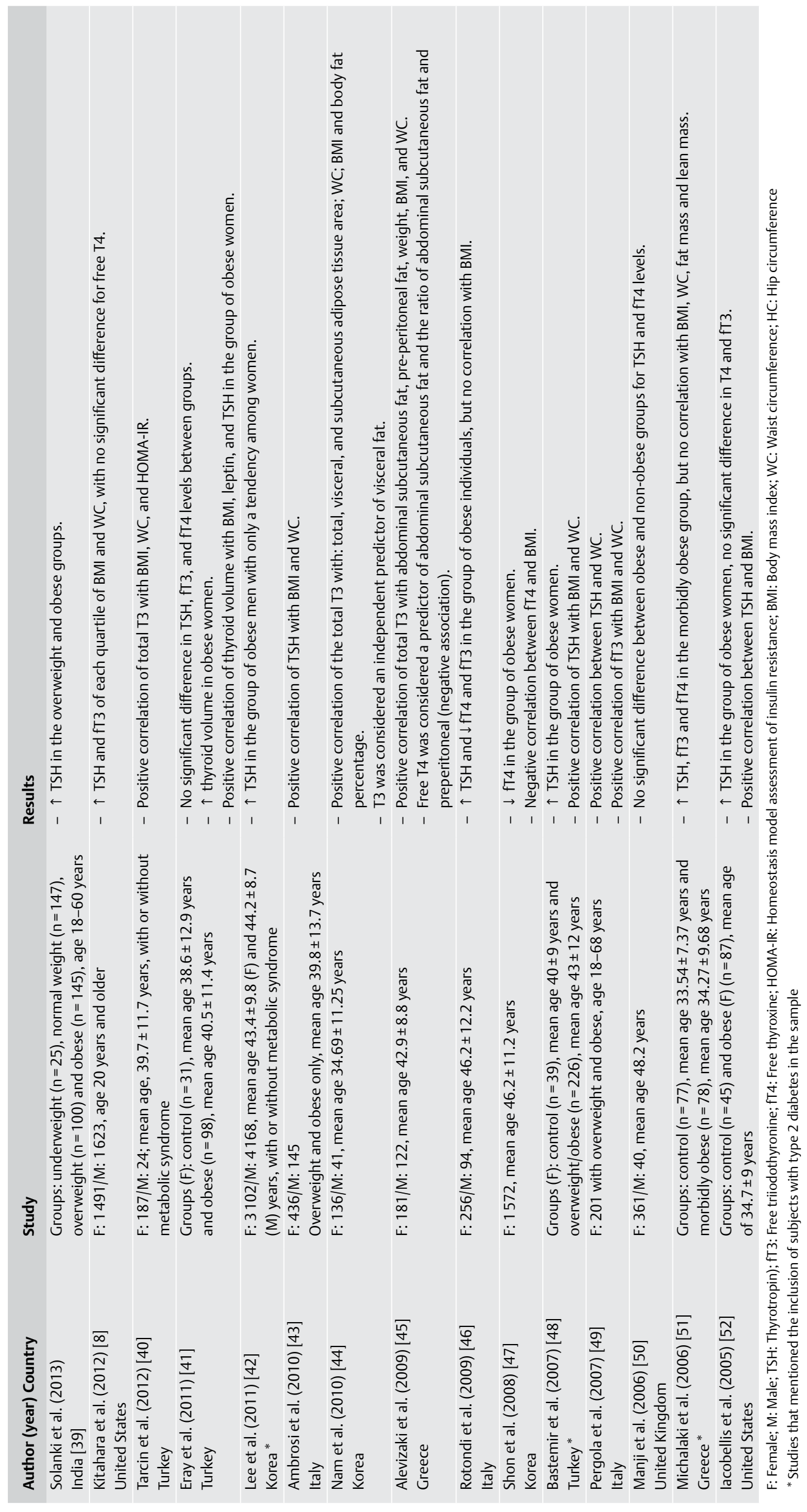




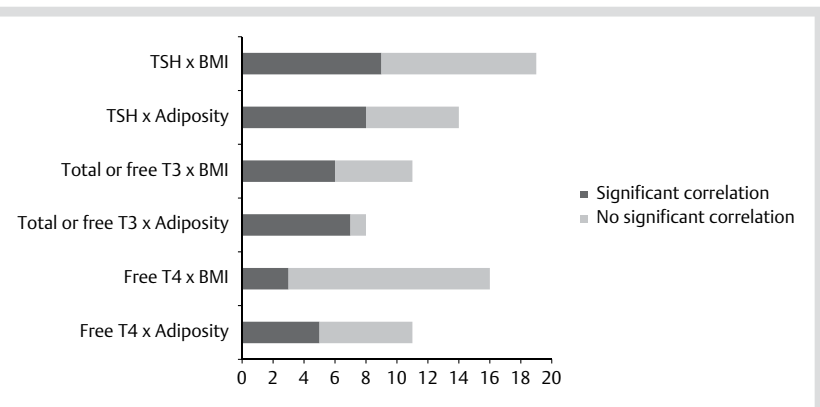

Fig. 1 Number of cross-sectional studies that evaluated the correlation between thyroid hormones, BMI, and adiposity markers in euthyroid obese adults (2005-2015). For TSH and T3: significant correlations were positive. For free T4: significant correlations were negative. Adiposity markers: waist circumference, waist-hip ratio, subcutaneous and preperitoneal fat layers, subcutaneous and visceral adipose tissue volume, subcutaneous and visceral adipose tissue area.

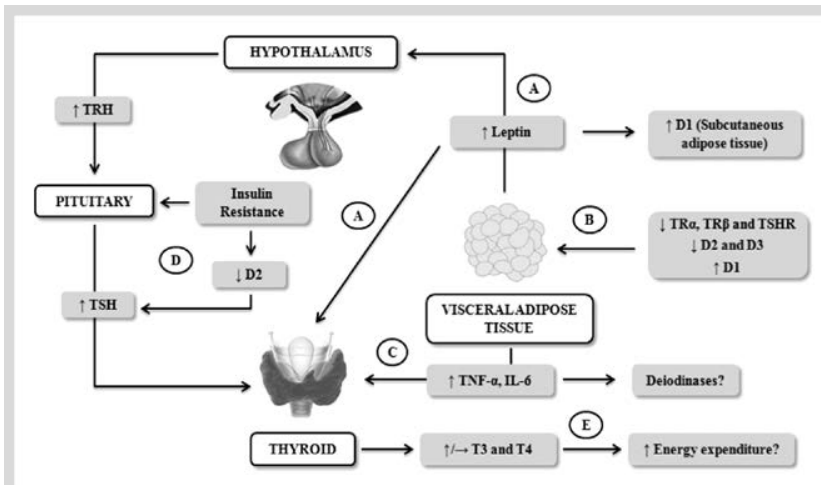

Fig. 2 Etiology of changes in thyroid hormones levels in obesity. a Hyperleptinemia stimulates the synthesis and secretion of TRH and TSH while simultaneously modulating the responsiveness of the thyroid gland to TSH, inhibiting the iodide uptake and expression of symporter sodium/ iodide and thyroglobulin. In addition, leptin influences the activity of deiodinases, in particular D1 in subcutaneous adipose tissue. b The change in the expression and activity of deiodinases enzymes, TR $\alpha$ and TR $\beta$ receptors and TSHR promote a resistance state to the action of thyroid hormones. c The inflammatory adipokines compromise thyroid function, contributing to morphological changes in the gland. In addition, there is the assumption that these adipokines may also alter the activity of deiodinases. $\mathbf{d}$ The insulin resistance in obesity seems to contribute to the D2 activity reduction in thyrotrophic cells, leading to tissue hypothyroidism and subsequent increase in TSH synthesis. e All of these mechanisms lead to changes in serum TSH, T3, and T4, which may lead to increase energy expenditure and affect the metabolic regulation of body tissues.

However, due to the presence of selective leptin resistance in the arcuate nucleus of the hypothalamus in obesity, the main route of modulation of the hypothalamic-pituitary-thyroid axis is through the direct action of this adipokine on the paraventricular nucleus [66-68]. In addition, leptin also promotes the synthesis of TRH at the post-translational level by inducing, via STAT3, expression of the enzymes prohormone convertases 1 (PC1/3) and 2 (PC2), which participate in the proteolytic cleavage of pro-TRH to its biologically active form [69].

In this context, studies have shown a positive correlation between serum TSH concentrations and leptin in obese individuals, which remained significant even after adjustment for body mass index (BMI), suggesting that high TSH values seem to be more related to energy balance than to adiposity $[30,33,52]$.
Leptin also appears to influence the metabolism of thyroid hormones by regulating the activity of deiodinase enzymes in different tissues [70]. In this regard, it is worth mentioning that changes in the activity of these enzymes may occur in obesity, with increase in D1 activity in the liver, kidney, and thyroid, and reduction of D2 activity in brown adipose tissue and the pituitary being observed [71,72]. In particular, animal and human studies have shown a positive relationship between leptin and D1 expression and/or activity in white adipose tissue $[73,74]$. In a study by Ortega et al. [74], high expression of D1 was observed in adipose tissue, which correlated positively with leptin expression, particularly in subcutaneous adipose tissue. These results suggest that leptin, which is synthesized by adipocytes, seems to stimulate the expression and local activity of D1, increasing the intracellular production of T3 in adipocytes, and thereby modulating the metabolism of this tissue. However, it is noteworthy that thyroid hormone receptor expression is reduced in adipocytes, which can impair the local action of T3, as explained below.

It is also important to stress that binding of TSH to its receptors on adipocytes appears to promote leptin secretion by these cells, suggesting the existence of a complex positive feedback mechanism between these 2 hormones [75,76]. Furthermore, T3 also appears to modulate leptin gene expression in cultured adipocytes as demonstrated by Oliveira et al. [77].

\section{Thyroid hormones resistance}

Resistance to thyroid hormones is a genetic disorder in which there is a reduction of the affinity for $\mathrm{T} 3$ of thyroid receptor ligands associated with irreversible interaction of co-repressors to these receptors. The most common form involves mutations in $\beta$ receptors (TR $\beta$ ) characterized by elevated serum levels of T3 and T4, and normal or slightly increased TSH concentrations. On the other hand, mutations in $\alpha$ receptors (TR $\alpha$ ) promote increase in serum T3, while TSH and T4 remain normal, and are associated with increased cholesterol and BMI [24].

Several studies have correlated the presence of certain genetic polymorphisms in thyroid receptors or molecules in its signaling pathway to the obesity risk $[56,57]$. Accordingly, Fernandez-Real et al. [78], analyzing 2 types of polymorphisms in TR $\alpha$, found that individuals with the $G$ allele related to the polymorphism rs1568400 ( $-635 \mathrm{~A} / \mathrm{G}$ ) had increased BMI, waist circumference, and levels of cholesterol and triglycerides, with a 2.3 times higher incidence of obesity in homozygotes. Another less frequent polymorphism, rs12939700 (A/C), was also associated with obesity in a group considered at high cardiovascular risk. These genetic factors indicate that resistance to thyroid hormones is related to the etiology of obesity. However, recent research suggests that this disease can also induce a resistance to these hormones, characterized by changes in expression of thyroid receptors in adipocytes. These alterations seem to be more pronounced in visceral adipose tissue, but may also be present in other tissues $[55,62,79,80]$.

In this context, the study by Nannipieri et al. [55] on morbid obesity has verified the lowered TSH receptor (TSHR) expression in adipose tissue, particularly visceral fat, and a tendency towards reduction of TR $\alpha 1$ expression. The expression of these receptors is inversely correlated with BMI, so that weight loss favored increased expression of both receptors in subcutaneous adipose tissue. The authors suggest the presence of peripheral resistance to thyroid hormones, which could have led to increased plasma concentrations of TSH and free T3 in these individuals, and that 
this condition can be reversed by weight loss. In accordance with this hypothesis, Kurylowicz et al. [62] found reduced expression of TR $\alpha$ in visceral adipose tissue and TR $\beta$ in visceral and subcutaneous adipose tissue of morbidly obese patients.

On the other hand, Lu et al. [81] found elevated expression of TSHR in adipocytes of subcutaneous adipose tissue of the cervical region in overweight individuals, and observed a trend towards increased expression of this receptor with increasing BMI. These conflicting results may be due to the location of the adipose tissue evaluated and show the complexity of the regulatory action of thyroid hormones in the body.

\section{Inflammation}

Chronic low-grade inflammation, a characteristic of obesity, also appears to be related to thyroid dysfunction. In the study of Roef et al. [14] on euthyroid adults, a positive correlation was observed between free T3/T4 ratio and serum concentrations of interleukin 6 (IL-6) and high-sensitivity C-reactive protein (hs(RP), regardless of body weight and waist circumference. Chen et al. [82] found a positive correlation between the BMI of children and adolescents and the volume of the thyroid, which also showed a positive correlation with hs-CRP concentrations.

In this regard, investigations have shown that inflammatory cytokines such as tumor necrosis factor $\alpha$ (TNF- $\alpha$ ) and IL-1 and 6 , can inhibit the mRNA expression of symporter sodium/iodide thus compromising iodide uptake activity in human thyroid cells [83-85]. These adipokines can still induce vasodilation and increased permeability of blood vessels in the thyroid that may contribute to morphological changes in this gland [85-87].

Rotondi et al. [87] found morphological changes in thyroid patients with morbid obesity, characterized by the presence of a hypoechogenic pattern on ultrasound in the absence of thyroid abnormalities. In the study conducted by Eray et al. [41], the volume of the thyroid was positively correlated with BMI, serum leptin and TSH concentrations, with reduction in the volume of the gland being observed 6 months after weight loss intervention.

With regard to the leptin role in chronic inflammation and, consequently, in morphological changes of the thyroid gland, a study with cultured thyroid cells in rats showed that this adipokine, as well as inflammatory cytokines, are capable of inhibiting iodide uptake and expression of the sodium/iodide symporter and thyroglobulin induced by TSH. This action suggests the presence of a modulating effect of leptin on responsiveness of thyroid cells to $\mathrm{TSH}$, which may partially explain the changes in thyroid hormones concentrations in obese individuals [88].

Another important aspect is that inflammation may also affect thyroid function by regulating the expression and/or activity of deiodinases in different body tissues, as shown by studies investigating the action of inflammatory cytokines in models of acute or chronic infectious inflammation [89-91]. However, the mechanisms involved in the regulation of deiodinases by chronic inflammation present in obese individuals are not yet clarified.

\section{Insulin resistance}

Insulin resistance is a common disorder in obesity and is characterized by impaired insulin action in metabolically active organs and tissues. The relationship between this metabolic disorder and thyroid hormones levels has been widely investigated because of the strong association of thyroid hormones and glucose homeostasis and also because of the insulin influence in the function of brain target regions such as the hypothalamus [24,92,93].
Some studies in humans have revealed the existence of a positive association between serum TSH and insulin resistance markers $[37,43,48,94]$. However, the mechanisms involved in the insulin action on the hypothalamic-pituitary-thyroid axis have not yet been elucidated. According to some authors, the insulin resistance in obesity seems to contribute to the D2 activity reduction in thyrotrophic cells, leading to tissue hypothyroidism and subsequent increase in TSH synthesis [51,93,94]. This hypothesis was proposed from results of an in vitro study that showed the role of insulin in promoting the activity of deiodinase in hepatocytes from fasted rats [95].

It is noteworthy that the positive association between TSH and insulin resistance in obesity appears to be mediated by adipose tissue $[8,10]$. In this regard, the increase in serum TSH levels may stimulate the synthesis of inflammatory cytokines by adipocytes and thus indirectly promote this metabolic disorder [96]. A recent study showed that TSH inhibits insulin-stimulated Akt phosphorylation in differentiated human adipocytes, which also may contribute to the insulin resistance observed in obesity [97]. Concerning the relationship between free T3 and glucose homeostasis in obesity, some studies show a positive correlation between serum concentrations of this hormone and insulin resistance markers $[11,40]$. It is known that $\mathrm{T} 3$ regulates the metabolic processes of gluconeogenesis and insulin secretion and function; however, the precise mechanisms by which the concentrations of this hormone could influence glucose homeostasis in obese individuals have not yet been elucidated [24].

\section{Final Considerations}

$\nabla$

The metabolism of thyroid hormones in obesity is influenced by several factors that alter their homeostatic control, which is reflected by changes in their serum levels. These changes probably occur in specific tissues, influencing the metabolism of every organ and system differently. Although several mechanisms have been proposed to explain the changes in thyroid hormone concentrations in obesity, its etiology is still unclear, and it is not possible to define the long-term clinical implications for obese individuals. From this perspective, it is necessary to perform longitudinal studies that seek to investigate the influence of obesity on thyroid function and its relationship with the risk of developing diseases.

\section{Conflict of Interest}

$\nabla$

The authors declare no conflict of interest.

\section{References}

1 Gregor MF, Hotamisligil GS. Inflammatory mechanisms in obesity. Annu Rev Immunol 2011; 29: 415-445

2 Rupérez AI, Gil A, Aguilera CM. Genetics of oxidative stress in obesity. Int J Mol Sci 2014; 15: 3118-1144

3 Bays HE, González-Campoy MJ, Bray GA, Kitabchi AE, Bergman DA, Schorr $A B$, Rodbard HW, Henry RR. Pathogenic potential of adipose tissue and metabolic consequences of adipocyte hypertrophy and increased visceral adiposity. Expert Rev Cardiovasc Ther 2008; 6: 343-368

4 Trayhurn $P$. Hypoxia and adipose tissue function and dysfunction in obesity. Physiol Rev 2013; 93: 1-21

5 Álvarez-Castro P, Sangiao-Alvarellos S, Brandón-Sandá I, Cordido F. Función endocrina en la obesidad. Endocrinol Nutr 2011; 58: 422-432

6 Biggs RB, Urzúa EA, González MM. El tejido graso como modulador endocrino: cambios hormonales asociados a la obesidad. Rev Med Chile 2010; 138: 1294-1301 
7 Bétry C, Challan-Belval MA, Bernard A, Charrié A, Drai J, Laville M, Thivolet $C$, Disse E. Increased TSH in obesity: evidence for a BMI-independent association with leptin. Diabetes Metab 2015; 41: 248-251

8 Kitahara CM, Platz EA, Ladenson PW, Mondul AM, Menke A, González AB. Body fatness and markers of thyroid function among U.S. men and women. PLoS One 2012; 7: e34979

9 Lambrinoudaki I, Armeni E, Rizos D, Georgiopoulos G, Athanasouli F, Triantafyllou N, Panoulis K, Augoulea A, Creatsa M, Alexandrou A, Alevizaki M, Stamatelopoulos $K$. Indices of adiposity and thyroid hormones in euthyroid postmenopausal women. Eur J Endocrinol 2015; 173: 237-245

10 Muscogiuri G, Sorice GP, Mezza T, Prioletta A, Lassandro AP, Pirronti T, Della Casa S, Pontecorvi A, Giaccari A. High-normal TSH values in obesity: is it insulin resistance or adipose tissue's guilt? Obesity (Silver Spring) 2013; 21: 101-106

11 Ren R, Jiang X, Zhang X, Guan Q Yu C, Li Y, Gao L, Zhang H, Zhao J. Association between thyroid hormones and body fat in euthyroid subjects. Clin Endocrinol (Oxf) 2014; 80: 585-590

12 Marcello MA, Cunha LL, Batista FA, Ward LS. Obesity and thyroid cancer. Endocr Relat Cancer 2014; 21: T255-T271

13 Oh JY, Sung YA, Lee HJ. Elevated thyroid stimulating hormone levels are associated with metabolic syndrome in euthyroid young women. Korean J Intern Med 2013; 28: 180-186

14 Roef GL, Rietzschel ER, Van Daele CM, Taes YE, De Buyzere ML, Gillebert TC, Kaufman JM. Triiodothyronine and free thyroxine levels are differentially associated with metabolic profile and adiposity-related cardiovascular risk markers in euthyroid middle-aged subjects. Thyroid 2014; 24: 223-231

15 Taylor PN, Razvi S, Pearce SH, Dayan CM. A review of the clinical consequences of variation in thyroid function within the reference range. J Clin Endocrinol Metab 2013; 98: 3562-3571

16 Wang X, Liu H, Chen J, Huang Y, Li L, Rampersad S, Qu S. Metabolic characteristics in obese patients complicated by mild thyroid hormone deficiency. Horm Metab Res 2016; 48: 331-337

17 Vaisman M, Rosenthal D, Carvalho DP. Enzimas envolvidas na organificação tireoidiana do iodo. Arq Bras Endocrinol Metab 2004; 48: 7-13

18 Hall JE. Hormônios metabólicos da tireoide. In: Hall JE. Tratado de fisiologia médica. Rio de Janeiro: Elsevier; 2011: 955-967

19 Abdalla SM, Bianco AC. Defending plasma T3 is a biological priority. Clin Endocrinol (Oxf.) 2014; 81: 633-641

20 Visser TJ, Peeters RP. Metabolism of thyroid hormone. In: De Groot LJ.(ed) Endotext - Thyroid disease manager [Internet]. South Dartmouth: MDText.com; 2012

21 Davis PJ, Goglia F, Leonard JL. Nongenomic actions of thyroid hormone. Nat Rev Endocrinol 2016; 12: 111-121

22 Marsili A, Zavacki AM, Harney JW, Larsen PR. Physiological role and regulation of iodothyronine deiodinases: a 2011 update. J Endocrinol Invest 2011 34: 395-407

23 Hoermann R, Midgley JEM, Larisch R, Dietrich JW. Homeostatic control of the thyroid-pituitary axis: perspectives for diagnosis and treatment. Front Endocrinol (Lausanne) 2015; 6: 177

24 Mullur R, Liu Y, Brent GA. Thyroid hormone regulation of metabolism. Physiol Rev 2014; 94: 355-382

25 Hoermann R, Midgley JEM, Larisch R, Dietrich JW. Integration of peripheral and glandular regulation of triiodothyronine production by thyrotropin in untreated and thyroxine-treated subjects. Horm Metab Res 2015; 47: 674-680

26 Little AG. A review of the peripheral levels of regulation by thyroid hormone. J Comp Physiol B 2016; 186: 677-688

27 Pearce EN. Thyroid hormone and obesity. Curr Opin Endocrinol Diabetes Obes 2012; 19: 408-413

28 Santini F, Marzullo P, Rotondi M, Ceccarini G, Pagano L, Ippolito S, Chiovato $L$, Biondi $B$. The crosstalk between thyroid gland and adipose tissue: signal integration in health and disease. Eur J Endocrinol 2014; 171: R137-R152

29 Bjergved L, Jørgensen $T$, Perrild $H$, Laurberg $P$, Krejbjerg A, Ovesen $L$, Rasmussen LB, Knudsen $N$. Thyroid function and body weight: a community-based longitudinal study. PLoS One 2014; 9: e93515

30 Soriguer F, Valdes S, Morcillo S, Esteva I, Almaraz MC, Adana MSR, Tapia MJ, Dominguez M, Gutierrez-Repiso C, Rubio-Martin E, Garrido-Sanchez L, Perez V, Garriga MJ, Rojo-Martinez G, Garcia-Fuentes E. Thyroid hormone levels predict the change in body weight: a prospective study. Eur J Clin Invest 2011; 41: 1202-1209

31 Ortega E, Pannacciulli N, Bogardus C, Krakoff J. Plasma concentrations of free triiodothyronine predict weight change in euthyroid persons. Am J Clin Nutr 2007; 85: 440-445

32 Knudsen N, Laurberg P, Rasmussen LB, Bülow I, Perrild H, Ovesen L, Jørgensen $T$. Small differences in thyroid function may be important for body mass index and the occurrence of obesity in the population. J Clin Endocrinol Metab 2005; 90: 4019-4024
33 Bétry C, Challan-Belval MA, Bernard A, Charrié A, Drai J, Laville M, Thivolet $C$, Disse $E$. Increased TSH in obesity: evidence for a BMI-independent association with leptin. Diabetes Metab 2015; 41: 248-251

34 Bakiner O, Bozkirli E, Cavlak G, Ozsahin K, Ertorer E. Are plasma thyroid-stimulating hormone levels associated with degree of obesity and metabolic syndrome in euthyroid obese patients? A turkish cohort study. Endocrinol 2014; 803028

35 Sakurai M, Nakamura K, Miura K, Yoshita K, Takamura T, Nagasawa S, Morikawa Y, Ishizaki M, Kido T, Naruse Y, Nakashima M, Nogawa $K$, Suwazono Y, Nakagawa H. Association between a serum thyroidstimulating hormone concentration within the normal range and indices of obesity in Japanese men and women. Intern Med 2014; 53: 669-674

36 Shinkov A, Borissova A, Kovatcheva R, Atanassova I, Vlahov J, Dakovska $L$. The prevalence of the metabolic syndrome increases through the quartiles of thyroid stimulating hormone in a population-based sample of euthyroid subjects. Endocrinol Metab 2014; 58: 926-932

37 Kouidhi S, Berhouma R, Ammar M, Rouissi K, Jarboui S, ClergetFroidevaux M, Seugnet I, Abid H, Bchir F, Demeneix B, Guissouma $H$, Elgaaied $A B$. Relationship of thyroid function with obesity and type 2 diabetes in euthyroid Tunisian subjects. Endocr Res 2013; 38: 15-23

38 Milionis A, Milionis C. Correlation between Body Mass Index and thyroid function in euthyroid individuals in Greece. Biomarkers 2013; 651494

39 Solanki A, Bansal S, Jindal S, Saxena V, Shukla US. Relationship of serum thyroid stimulating hormone with body mass index in healthy adults. Indian J Endocrinol Metab 2013; 17 (Suppl 1): 167-169

40 Tarcin O, Abanonu GB, Yazici D, Tarcin O. Association of metabolic syndrome parameters with TT3 and FT3/FT4 ratio in obese Turkish population. Metab Syndr Relat Disord 2012; 10: 137-142

41 Eray E, Sari F, Ozdem S, Sari $R$. Relationship between thyroid volume and iodine, leptin, and adiponectin in obese women before and after weight loss. Med Princ Pract 2011; 20: 43-46

42 Lee YK, Kim JE, Oh HJ, Park KS, Kim SK, Park SW, Kim MJ, Cho YW. Serum TSH level in healthy Koreans and the association of TSH with serum lipid concentration and metabolic syndrome. Korean J Intern Med 2011; 26: 432-439

43 Ambrosi B, Masserini B, Iorio L, Delnevo A, Malavazos AE, Morricone L, Sburlati $L F$, Orsi $E$. Relationship of thyroid function with body mass index and insulin-resistance in euthyroid obese subjects. J Endocrinol Invest 2010; 33: 640-643

44 Nam JS, Cho M, Park JS, Ahn CW, Cha BS, Lee EJ, Lim SK, Kim KR, Lee HC. Triiodothyronine level predicts visceral obesity and atherosclerosis in euthyroid, overweight and obese subjects: T3 and visceral obesity. Obes Res Clin Pract 2010; 4: e247-e342

45 Alevizaki M, Saltiki K, Voidonikola P, Mantzou E, Papamichael C, Stamatelopoulos $K$. Free thyroxine is an independent predictor of subcutaneous fat in euthyroid individuals. Eur J Endocrinol 2009; 161: 459-465

46 Rotondi M, Leporati P, Manna A, Pirali B, Mondello T, Fonte R, Magri F, Chiovato $L$. Raised serum TSH levels in patients with morbid obesity: is it enough to diagnose subclinical hypothyroidism? Eur J Endocrinol 2009; 160: 403-408

47 Shon HS, Jung ED, Kim SH, Lee JH. Free T4 is negatively correlated with body mass index in euthyroid women. Korean J Intern Med 2008; 23: $53-57$

48 Bastemir M, Akin F, Alkis E, Kaptanoglu B. Obesity is associated with increased serum TSH level, independent of thyroid function. Swiss Med Wkly 2007; 137: 431-434

49 Pergola G, Ciampolillo A, Paolotti S, Trerotoli P. Giorgino Free triiodothyronine and thyroid stimulating hormone are directly associated with waist circumference, independently of insulin resistance, metabolic parameters and blood pressure in overweight and obese women. Clin Endocrinol (Oxf.) 2007; 67: 265-269

50 Manji N, Boelaert K, Sheppard MC, Holder RL, Gough SC, Franklyn JA. Lack of association between serum TSH or free T4 and body mass index in euthyroid subjects. Clin Endocrinol (Oxf.) 2006; 64: 125-128

51 Michalaki MA, Vagenakis AG, Leonardou AS, Argentou MN, Habeos IG Makri MG, Psyrogiannis AI, Kalfarentzos FE, Kyriazopoulou VE. Thyroid function in humans with morbid obesity. Thyroid 2006; 16: 73-78

52 Iacobellis G, Ribaudo MC, Zappaterreno A, Iannucci CV, Leonetti F. Relationship of thyroid function with body mass index, leptin, insulin sensitivity and adiponectin in euthyroid obese women. Clin Endocrinol (Oxf.) 2005; 62: 487-491

53 Lauberg P, Knudsen N, Andersen S, Carlé A, Pedersen IB, Karmisholt J. Thyroid function and obesity. Eur Thyroid J 2012; 1: 159-167 
54 Lips MA, Pijl H, van Klinken JB, de Groot GH, Janssen IM, Ramshorst $B V$, BAV Wagensveld, Swank DJ, Dielen FV, JWA Smit. Roux-en-Y gastric bypass and calorie restriction induce comparable time-dependent effects on thyroid hormone function tests in obese female subjects. Eur J Endocrinol 2013; 169: 339-347

55 Nannipieri M, Cecchetti F, Anselmino M, Camastra S, Niccolini P, Lamacchia $M$, Rossi $M$, Iervasi $G$, Ferrannini $E$. Expression of thyrotropin and thyroid hormone receptors in adipose tissue of patients with morbid obesity and/or type 2 diabetes: effects of weight loss. Int J Obes (Lond.) 2009; 33: 1001-1006

56 Pacifico L, Anania C, Ferraro F, Andreoli GM, Chiesa C. Thyroid function in childhood obesity and metabolic comorbidity. Clin Chim Acta 2012; 413: 396-405

57 Reinehr T. Obesity and thyroid function. Mol Cell Endocrinol 2010; 316: 165-171

58 Vaitkus JA, Farrar JS, Celi FS. Thyroid hormone mediated modulation of energy expenditure. Int J Mol Sci 2015; 16: 16158-16175

59 Carneiro IP, Elliott SA, Siervo M, Padwal R, Bertoli S, Battezzati A, Prado CM. Is obesity associated with altered energy expenditure? Adv Nutr 2016; 7: 476-487

60 Spadafranca A, Cappelletti C, Leone A, Vignati L, Battezzati A, Bedogni $G$, Bertoli $S$. Relationship between thyroid hormones, resting energy expenditure and cardiometabolic risk factors in euthyroid subjects. Clin Nutr 2015; 34: 674-678

61 Wright TG, Dawson B, Jalleh G, Guelfi KJ. Influence of hormonal profile on resting metabolic rate in normal, overweight and obese individuals. Ann Nutr Metab 2015; 66: 162-167

62 Kurylowicz A, Jonas M, Lisik W, Jonas M, Wicik ZA, Wierzbicki Z, Chmura A, Puzianowska-Kuznicka M. Obesity is associated with a decrease in expression but not with the hypermethylation of thermogenesisrelated genes in adipose tissues. J Transl Med 2015; 13: 31

63 Ghamari-Langroudi M, Vella KR, Srisai D, Sugrue ML, Hollenberg AN, Cone $R D$. Regulation of thyrotropin-releasing hormone-expressing neurons in paraventricular nucleus of the hypothalamus by signals of adiposity. Mol Endocrinol 2010; 24: 2366-2381

64 Hollenberg AN. The role of the thyrotropin-releasing hormone (TRH) neuron as a metabolic sensor. Thyroid 2008; 18: 131-139

65 Sande-Lee S, Velloso LA. Disfunção hipotalâmica na obesidade. Arq Bras Endocrinol Metab 2012; 56: 341-350

66 Enriori PJ, Evans AE, Sinnayah P, Jobst EE, Tonelli-Lemos L, Billes SK, Glavas MM, Grayson BE, Perello M, Nillni EA, Grove KL, Cowley MA. Diet-induced obesity causes severe but reversible leptin resistance in arcuate melanocortin neurons. Cell Metab 2007; 5: 181-194

67 Münzberg H, Flier JF, Bjørbæk C. Region-specific leptin resistance within the hypothalamus of diet-induced obese mice. Endocrinology 2004; 145: 4880-4889

68 Perello M, Çakir I, Cyr NE, Romero A, Stuart RC, Chiappini F, Hollenberg $A N$, Nillni EA. Maintenance of the thyroid axis during diet-induced obesity in rodents is controlled at the central level. Am J Physiol Endocrinol Metab 2010; 299: E976-E989

69 Nillni EA. Minireview: regulation of prohormone convertases in hypothalamic neurons: implications for prothyrotropin-releasing hormone and proopiomelanocortin. Endocrinology 2007; 148: 4191-4200

70 Cabanelas A, Lisboa PC, Moura EG, Pazos-Moura CC. Acute effects of leptin on 5'-deiodinases are modulated by thyroid state of fed rats. Horm Metab Res 2007; 39: 818-822

71 Araújo RL, Carvalho DP. Bioenergetic impact of tissue-specific regulation of iodothyronine deiodinases during nutritional imbalance. J Bioenerg Biomembr 2011; 43: 59-65

72 Araújo RL, Andrade BM, Padrón AS, Gaidhu MP, Perry RLS, Carvalho $D P$, Ceddia RB. High-fat diet increases thyrotropin and oxygen consumption without altering circulating 3,5,3'-Triiodothyronine (T3) and thyroxine in rats: the role of iodothyronine deiodinases, reverse T3 production, and whole-body fat oxidation. Endocrinology 2010; 151: 3460-3469

73 Jílková ZM, Pavelka S, Flachs P, Hensler M, Kůs V, Kopecký J. Modulation of type I iodothyronine $5^{\prime}$-deiodinase activity in white adipose tissue by nutrition: possible involvement of leptin. Physiol Res 2010; 59: 561-569

74 Ortega FJ, Jílková ZM, Moreno-Navarrete JM, Pavelka S, Rodriguez-Hermosa JI, Kopecký J, Fernández-Real JM. Type I iodothyronine 5'-deiodinase mRNA and activity is increased in adipose tissue of obese subjects. Int J Obes (Lond.) 2012; 36: 320-324

75 Duntas LH, Biondi B. The interconnections between obesity, thyroid function, and autoimmunity: the multifold role of leptin. Thyroid 2013; 23: 646-653
76 Santini F, Galli G, Maffei M, Fierabracci P, Pelosini C, Marsili A, Giannetti M, Castagna MG, Checchi S, Molinaro E, Piaggi P, Pacini F, Elisei R, Vitti $P$, Pinchera A. Acute exogenous TSH administration stimulates leptin secretion in vivo. Eur J Endocrinol 2010; 163: 63-67

77 Oliveira M, Síbio MT, Olimpio RMC, Moretto FCF, Luvizotto RAM, Nogueira $C R$. Triiodothyronine modulates the expression of leptin and adiponectin in 3T3-L1 adipocytes. Einstein 2015; 13: 72-78

78 Fernández-Real JM, Corella D, Goumidi L, Mercader JM, Valdés S, RojoMartínez G, Ortega F, Martinez-Larrad M-T, Gómez-Zumaquero JM, Salas-Salvadó J, Martinez-González MA, Covas MI, Botas P, Delgado E, Cottel D, Ferrieres J, Amouyel P, Ricart W, Ros E, Meirhaeghe A, SerranoRios $M$, Soriguer F, Estruch $R$. Thyroid hormone receptor alpha gene variants increase the risk of developing obesity and show gene-diet interactions. Int J Obes (Lond.) 2013; 37: 1499-1505

79 Bairras C, Redonnet A, Dabadie H, Gin H, Atgie C, Pallet V, Higueret P, Nöel-Suberville C. RAR $\gamma$ and TR $\beta$ expressions are decreased in PBMC and SWAT of obese subjects in weight gain. J Physiol Biochem 2010; 66: 29-37

80 Ortega FJ, Moreno-Navarrete JM, Ribas V, Esteve E, Rodriguez-Hermosa JI, Ruiz B, Peral B, Ricart W, Zorzano A, Fernández-Real JM. Subcutaneous fat shows higher thyroid hormone receptor- $\alpha 1$ gene expression than omental fat. Obesity 2009; 17: 2134-2141

81 Lu S, Guan Q Liu Y, Wang H, Xu W, Li X, Fu Y, Gao L, Zhao J, Wang X. Role of extrathyroidal TSHR expression in adipocyte differentiation and its association with obesity. Lipids Health Dis 2012; 11: 17

82 Chen $H$, Zhanga H, Tang W, Xi Q, Liu X, Duan Y, Liu C. Thyroid function and morphology in overweight and obese children and adolescents in a Chinese population. J Pediatr Endocr Met 2013; 26: 489-496

83 Ajjan RA, Watson PF, Findlay C, Metcalfe RA, Crisp M, Ludgate M, Weetman $A P$. The sodium iodide symporter gene and its regulation by citokines found in autoimmunity. J Endoncrinol 1998; 158: 351-308

84 Schumm-Draeger PM. Sodium/iodide symporter (NIS) and cytokines. Exp Clin Endocrinol Diabetes 2001; 109: 32-44

85 Longhi S, Radetti G. Thyroid function and obesity. J Clin Res Pedriatr Endocrinol 2013; 5 (Suppl 1): 40-44

86 Chrousos GP. The hypothalamic-pituitary-adrenal axis and immunemediated inflammation. N Engl J Med 1995; 332: 1351-1362

87 Rotondi M, Cappelli C, Leporati P, Chytiris S, Zerbini F, Fonte R, Magri $F$, Castellano M, Chiovato $L$. A hypoechoic pattern of the thyroid at ultrasound does not indicate autoimmune thyroid diseases in patients with morbid obesity. Eur J Endocrinol 2010; 163: 105-109

88 Isozaki O, Tsushima T, Nozoe Y, Miyakawa M, Takano K. Leptin regulation of the thyroids: negative regulation on thyroid hormone levels in euthyroid subjects and inhibitory effects on iodide uptake and $\mathrm{Na}+/ \mathrm{I}-$ symporter mRNA expression in rat FRTL-5 cells. Endocr J 2004; 51: 415-423

89 Jakobs TC, Mentrup B, Schmutzler C, Dreher I, Köhrle J. Proinflammatory cytokines inhibit the expression and function of human type $\mathrm{I}$ 5'-deiodinase in HepG2 hepatocarcinoma cells. Eur J Endocrinol 2002; 146: 559-566

90 Boelen A, Kwakkel J, Alkemade A, Renckens R, Kaptein E, Kuiper G, Wiersinga WM, Visser TJ. Induction of type 3 deiodinase activity in inflammatory cells of mice with chronic local inflammation. Endocrinology 2005; 146: 5128-5134

91 Kwakkel J, Surovtseva OV, Vries EM, Stap J, Fliers E, Boelen A. A novel role for the thyroid hormone-activating enzyme type 2 deiodinase in the inflammatory response of macrophages. Endocrinology 2014; 155: 2725-2734

92 Hardy OT, Czech MP, Corvera S. What causes the insulin resistance underlying obesity? Curr Opin Endocrinol Diabetes Obes 2012; 19: 81-87

93 Kullmann S, Heni M, Hallschmid M, Fritsche A, Preissl H, Häring HU. Brain insulin resistance at the crossroads of metabolic and cognitive disorders in humans. Physiol Rev 2016; 96: 1169-1209

94 Galofré JC, Pujante P, Abreu C, Santos S, Guillen-Grima F, Frühbeck G, Salvador $J$. Relationship between thyroid-stimulating hormone and insulin in euthyroid obese men. Ann Nutr Metab 2008; 53: 188-194

95 Gavin L, Cavalieri R, Moeller M. Glucose and insulin reverse the effects of fasting on 3,5,3'-triiodothyronine neogenesis in primary cultures of rat hepatocytes. Endocrinology 1987; 121: 858-864

96 Sorisky A, Antunes TT, Gagnon A. The adipocyte as a novel TSH Target. Mini Rev Med Chem 2008; 8: 91-96

97 Felske D, Gagnon A, Sorisky A. Interacting effects of TSH and insulin on human differentiated adipocytes. Horm Metab Res 2015; 47: 681-685 